\title{
Study on Improving the Transformation of Scientific and Technological Achievements Profit Distribution in Chinese Universities
}

\author{
Na Deng Haosi Chen \\ Shanghai university of engineering science \\ Dn918@163.com Haosihaosi@163.com
}

\begin{abstract}
This paper on scientific and technological achievements transformation of Chinese colleges and universities of problems existing in the income distribution has carried on the profound elaboration, and through the survey analysis domparison research method, according to China's relevant policies of colleges and universities, the disposition and distribution of scientific and technological achieyements, the intrinsic value of scientific and technological achievements market etc. Put forward some countermeasures and Suggestions, has certain operability.
\end{abstract}

Keywords: Transformation; Scientificand techñological achievements; profit distribution

\section{Introduction}

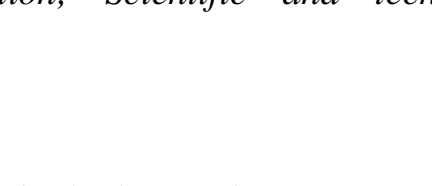

Colleges and universities is the innovatiopresources centre, is an important source of scientific and technologicalihnovation. Reform and innovation of Chinese colleges and universities of science and technology áchievements transformation system of income distribution, the colleges and universities to better play a role of main force of science and technology innovation, and to implement the strategy of innovation driven development, speed up the transformation of the pattern of economic development, has the very vital significance.

\section{The Main Problems of Income Distribution Transformation of Scientific and Technological Achievements in Chinese Universities}

2.1. The Disposition and Distribution Right of Transformation of Scientific and Technogical Achievements in Chinese Universities is Limited

According to the regulation, intellectual property rights of scientific and technological achievements and become a shareholder, for 1 million yuan of the following should be submitted to the ministry of education for the record, for the following to be submitted to the ministry of education approval in 8 million, price is in 8 million yuan or more of the ministry of finance for approval by the ministry of education. In the real operation, the approval process trival long cycle and tend to affect the timing of the transformation of scientific and technological achievements.

The landing of university scientific research achievement transformation is often affected by the laboratory techniques have not market and application of enterprise channel is lack of project. University scientific research and development, pilot, industrial flow appears "break-chain" phenomenon. The development and transformation of scientific and technological achievements, is an important source to promote the development of the productive forces. Universities and research institutes over the years 
produced a large number of scientific and technological achievements. However, because of the achievements in science and Technology Research Institute, disposal and the right to return to management on the limitations, especially the transformation of scientific and technological achievements benefit distribution mechanism is not reasonable, generally larger project approval record of cumbersome and complex process, long period, science and technology staff's enthusiasm, creativity cannot be fully-play, restrict the transformation of scientific and technological achievements and industrialization, a lot of achievements did not translate into productivity.

\subsection{China Technology Market has Not Yet Formed into Income Total Factor Allocation Mechanism of Scientific and Technological Achievements}

Technical factors participate in the distribution of income encountered considerable difficulties in practice, mainly as follows: how to define the elements of technology, how to assess the contribution, how to deal with (Group) and (personal) relationship. In the specific operation is: technology assessment, definition of property rights difficult, difficult achievement ratio and the stock is difficult to determine the results of distribution.

The external system is not perfect is mainly: the laek of an effective policy support, lack of support and the lack of effective support reliabie organization. There is not really a law of distribution according to essential productive capital, technology and other benefits to disposal to make corresponding regulations, also affected the progress of technology participating in distribution of work in acertain extent.

Now the scientific research reward is a kind of atter of expediency, it does not reflect the distribution according to production factors achievement ownership. It is still the official results of property rights of exclusive possession, not reflected the development of human rights, not to see the Tesults in the production process of the group investment, did not see the individuar contribution and human resources into human capital reality, not seen in the development, in the process of transformation group asset accumulation of reality, developers in the dominated position.

\subsection{Chinese Current Transformation of Scientific and Technological Achievements Income Distribution of R \& D Personnel Incentive Policy is not Strong}

The current scientific and technological achievements Chinese incentive policies lack of corresponding measures and operating rules in the process of implementing, scientific and technological personnel not to protect the interests of science and technology, personnel incentive policy implementation is not in place, restricting the transformation of scientific and technological achievements and industrialization. Mainly as follows: the college title assessment according to Ministry of education evaluation system, resulting in curen college title assessment basically does not involve the related indicators of achievement transformation and technology transfer, the evaluation system is not conducive to scientific and technical personnel to carry out the transformation of scientific and technological achievements; have not yet formed asset management and the income distribution system of scientific research institutions in accordance with the characteristics of scientific and technological achievements transformation on the scientific and technical personnel; incentive policies are not in place; ability of enterprise transformation of scientific and technological achievements, cooperative interests distribution mechanism is not perfect; the pricing mechanism of technological achievements is not perfect, the intellectual property rights difficult, high cost of rights; the science and technology intermediary service lacks of support measures, service capacity needs to be improved; the transformation of scientific and technological achievements of investment and financing mechanism is not perfect. 


\subsection{The intrinsic value of scientific and technological achievements evaluation system is unreasonable, causing the market price and intrinsic value deviates from the scientific and technological achievements}

At present, the price of the technology Chinese formation mechanism is not reasonable, technology trading mainly technology production costs as the basis for pricing technology, leading technology obviously low price.

The formation of technology factor price depends not only on the willingness of both transactions, but also on the national industrial policy、market、 technology commodity supply-demand relationship、 technological competitiveness 、 economic prospects 、 technical transformation period、 transaction cost、 enterprise capacity and so on.

The formation of Chinese technology commodity transaction prices exist the following problems:

Technology commodity transaction price is significantly lower. The main reason is that:

(1)With the independent intellectual property rights of China existing technical development achievements of the project is less. The price of technology depends on the technology can bring economic benefits. With the independent intellectual property rights results due to the formation of technology monopoly for a certain period of time and a certain range, can bring higher economic Ancome for the technology owner, so the technology transfer price high. China tedhnology commodity trade price is low, it is important reflect less technology has a breakthrough.

(2)Technology as commodity profit rate islow. According to the experts from the mechanical, electrical, light industry three industry data, Chinese technology commodity profit commission rate averaged $11 \%$. UNUDO had investigation, statistics, analysis of technology contract price many world and actual profits, that the profit sharing rate is in commonly $16 \%, 27 \%, 20 \%$ under the more reasonable, that Chinese technology commodity prices are 10 .

The price of technology commodity is low is not conducive to encouraging independent innovation, is not conducive to encourage enterprises to transition from selling products to selling technology, is not conducive to attract social capital accumulation to the field of science and technology.

China technology transaction cost is high. Outstanding performance in:

(1) The relevant laws and regulations of technical market are not perfect. At present China actually still does not have a specific legal regulations of technical market, science and technology departments have no clear technology market supervision function, resuting in many specific technical trading behavior, the lack of legal basis, increase the technological trading risk cost.

(2) Technology market has not formed a network of the national market.The transaction cost is too high. At present China has not yet been established at the national level technology transaction information service platform of national unity, asymmetric information, increase the transaction cost.

(3)The technology transfer mechanism function needs to be improved. Currently engaged in technology assessment, agency, finance and market research agencies lack, some technology transfer property management system, unreasonable, poor service level.

(4)High quality technology management talent is scarce. High quality at present Chinese technology market personnel lack of high knowledge level, negotiation skills to understand technology law 、management and market personnel. 
(5)The investment into transformation of scientific and technological achievements is not sufficiency. Chinese universities science and technology achievement transformation investment and risk is mainly borne by the enterprises, leading enterprises in the process of the industrialization of scientific and technological achievements in the cost is too high, the risk is too large, affecting the commercialization of scientific and technological achievements effect.

\section{Research on improving the China universities science and technology achievement transformation of income allocation efficiency}

\subsection{Simplified Chinese universities into the process of scientific and technological achievements, give more right to income distribution}

We should give the full title of scientific and technological achievements Chinese right to dispose of rights and benefits, is clear about the subject status in the technology market, give scientific and operational autonomy; deal with national finance reseasch projects funded by the formation of scientific and technological Jachievements, except those involving state security and interests, disposal and the right to return fully to the University. We should encourage the establishment of a technícal background, and to understand the operation of the market and echnology management promotion of achievement of science and technology professional team in universities; guide the establishment of scientific and technologicar achievements appraisal model and transformation mechanism of independent college, reasonable disposition of scientific and technological achievements rights.

China national authorities should start as soon as the achievement of science and Technology University officiah pilot right system reform, explore the establishment of right of disposal income, which is different from the tangible assets of scientific and technological achievements and intellectual property management; perfect system of the transformation of scientific and technological achievements in office, ownership, valuation, pricing shares, the company, staff incentives and other aspects of the formation, the implementation details clear and unified; strengthen guidance and assessment of scientific and technological achievements transformation work in colleges, and promote scientific and technological achievements to speed up to enter the market, realize the value maximization.

3.2 Take the market as the mechanism configuration of resources of science and technology, as a link to form transformation of scientific and technological achievements income distribution of all elements

Labor, capital, technology and natural resources and other production factors participate in the distribution of income of scientific and technological achievements, to realize how much the size of contribution of factor of production and investment in accordance with their respective input production factors play their proper role in the premise of distribution. Therefore, Chinese emphasis should be built following the market:

(1) The visible technology market. Technology market is a place for technical exchange and domain, is a science and technology information, technology, commodity distributing center, it is advantageous to the technical commodity trading, the transformation of technological achievements, create conditions for technical factors participate in income distribution at the same time.

(2) The online technology market. Online technology market use modern network technology to make China's existing technology market. Online technology, project bidding is the biggest characteristic of online technology market. Online technology market has the characteristics of all-weather, informatization and high efficiency, 
overcome the limit of time and space, expanding the choice scope of supply and demand, will greatly accelerate the process of transformation of scientific and technological achievements.

(3) The human capital market. Around on the basis of the talent exchange center, accelerate the construction of the human capital market, break the old servant mechanism, implement talent of marketization socialization and internationalization, make the value of human capital in the flow.

(4) The capital market. To promote the development of the income distribution of all elements of scientific and technological achievements, to establish a guided by government funds, give priority to social capital to support multiple investment system of science and technology innovation. The government can use discount loans, /subsidy funds, credit guarantee support transformation of scientific and technological achievements. Technical personnel after the advent of new technologies, new products, to contract law, tort law, such as law, anti-unfair competition law to protect intellectual property rights of scientific and technological achievements, to maintain the lawful rights and interests of scientific and technological achievements pateht.

3.3 Improve the distribution of proceeds of Chinese science and technology achievements transformation of colleges and universities for research staff incentive policy

Make full use of market mechanism, and guide encourage researchers to adapt to the need of the development and prodaction practice, research and development, the transformation of scientific and technological achievements. According to "who, who owns, who benefits" principle, the reasonable definition of university and scientific research personnel property relations, has set up a unified technological achievements transfer conversion system. Give the imventor of scientific and technological achievements even greate dsufruct Encourage inventors more shareholding ways of scientific and technological achieyements transformation of achievements, to promote China's university researchers intolved in the scientific and technological achievements. Concrete from the following se veralaspects:

(1) China shall separately formulate standardized management in colleges and universities and research institutions of the implementation methods of intellectual property rights, the specification, the income attribution, profit sharing, examination and approval procedures, tax be explicitly guide, etc.

(2) In the aspect of law clear fiscal investment form the scientific and technological achievements of the ownership. China of intellectual property rights belong to the provisions of relevant laws and regulations of not clear disposition (including possession, dominanee and use), therefore, proposed to disposition gives scientific research projects, along with all the units, by the scientific research units with complete property rights in the transformation of scientific and technological achievements.

(3) China should give college scientific research institutions to develop specific allocation proportion of power. University scientific research institution has the right to make specific revenue sharing rules, in schools, colleges, inventor, and technology transfer mechanism between four to determine a reasonable and operable proportion, roughly part for personal gains, shall be constrained matching wage policy, tax policy.

(4) Establishing professional operational technology transfer organization, implementation technology transfer institutions and scientific research units, laboratories (department), the inventor of the Shared technology transfer income. 


\subsection{Prompting China's scientific and technological achievements of colleges and universities the intrinsic value is consistent with the market price as far as possible}

Determine the value of the new technology, need from the product or the technology itself and the way to trade, the reality of the market, and other comprehensive factors. From the intrinsic value of scientific research achievements, the mature patent technology is higher than the value of the proprietary technology, for the patent technology, the value of a patent for invention is much higher than that of utility model and appearance patents. In addition, compared with the value of a one-time transfer, transfer the value of one more time to play at least seven to eighty percent, the more of the transfer, its value will be affected by more; From the perspective of the market impact of new substitute products of core technology, it can be several times more than the value of growth; If there is a competitor, so will discount the value of the technology, competition, the more will affect the value of the technology content; Technology cost is too high, the conversion value must be at least reduce more than forty percent; Other comprehensive factors, such as national policy, regional development, industry of new technology, etc., will ultimately affect the value of a new technology or new products.

Therefore, colleges and universities of science and teehnology achievements transformation need to establish a standardized and scientific techno,logy value appraisal system, guarantee the reasonable interests of developers, respecting the rule of market value, and promote the transformation of scientific and technological achievements and technology transfer.

\section{Conclusion}

The university is the main sotrce of scientific and technological innovation, reform and innovation of China's income distribution system of scientific and technological achievements and methods is of great significance. In the allocation of scientific and technological achievements the author of this paper point out the lack of disposition and usufruct, unreasonablefincome distribution system, the internal value of scientific and technological achievements, analyzing the problems such as distortion and on this basis, put forward the simplify the disposal process of scientific and technological achievements, establish and improve the total factor distribution mechanism, encourage scientific and technologicalachievements intrinsic value is consistent with the market price, etc. Countermeasures and Suggestions. This article research, to establish and perfect the scientific and rational Chinese universities of science and technology achievements transformation system of income distribution has a certain reference value.

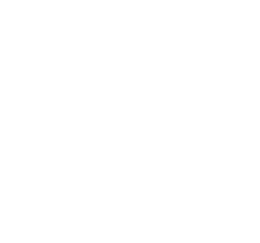




\section{References}

[1] Ines Macho-Stadler, David Perez-Castrillo. Incentives in university technology transfers Inernational Journal of Industrial Organization.vol.28,pp.362-367. (2010)

[2] H.Liu,Y.Zhou, The technology transfer policy system and its coordination mechanism research Scientific research management.vol.33,No.3,pp 105-111.March,(2012).

[3] W.Xue,S.J.Wei,The main problems and recommendations of tax policy for stock incentive in china, Science and technology of China BBS,vol.10,pp.30-36.(2013)

[4] S.Y.Wu, Editor, Intangible assets management and evaluation. The capital economic and trade university publishers, Beijing (2007).

[5] Y.C.Zhang, Editor, Study on mechanism of technology transfer. China economic publishing house pbilishers, Beijing (2009).

\section{Author}

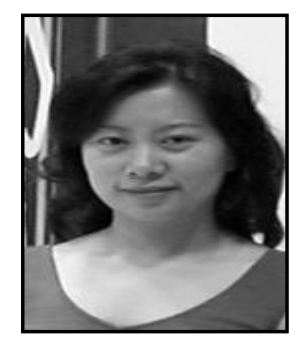

Na Deng, Female, (1977-), The main research scientific research management

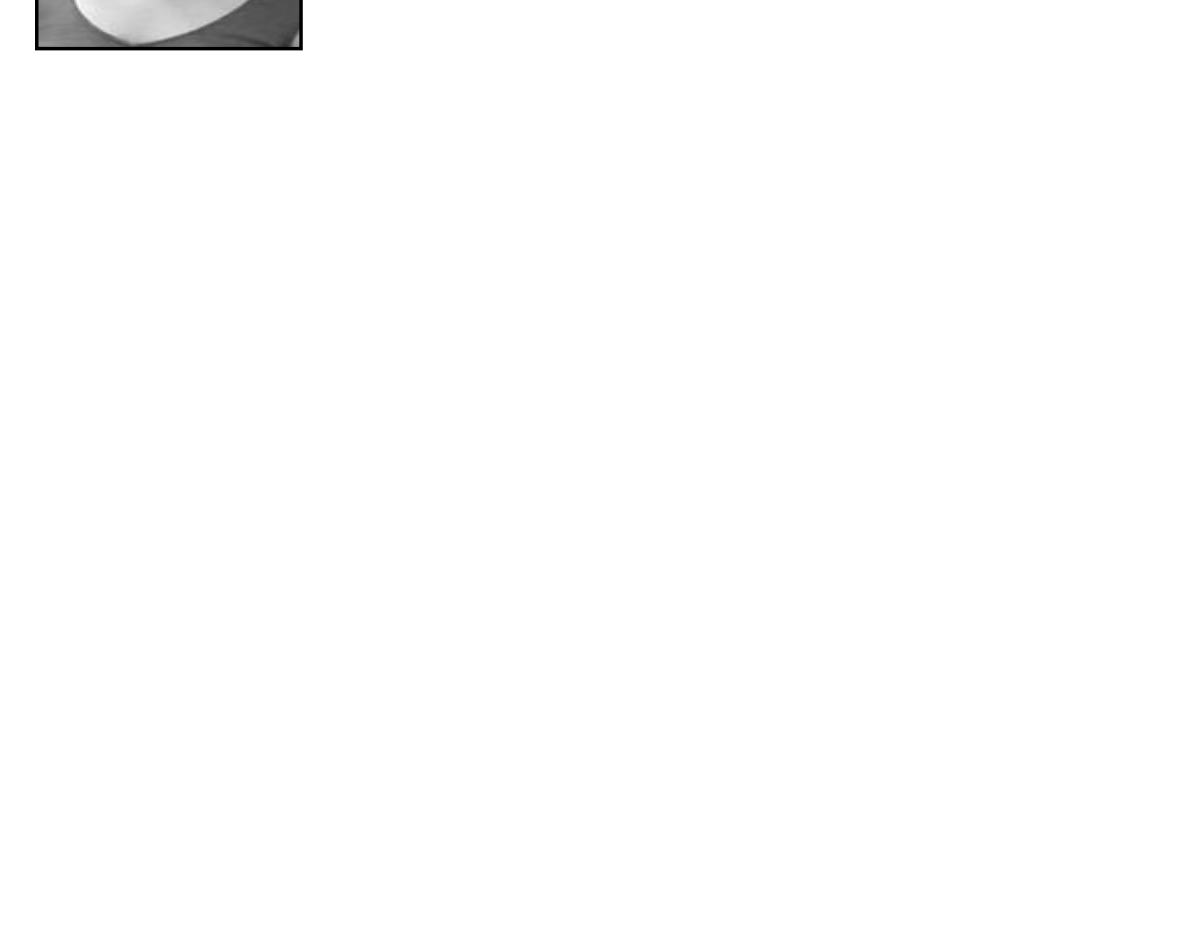


International Journal of Multimedia and Ubiquitous Engineering

Vol.9, No.8 (2014)

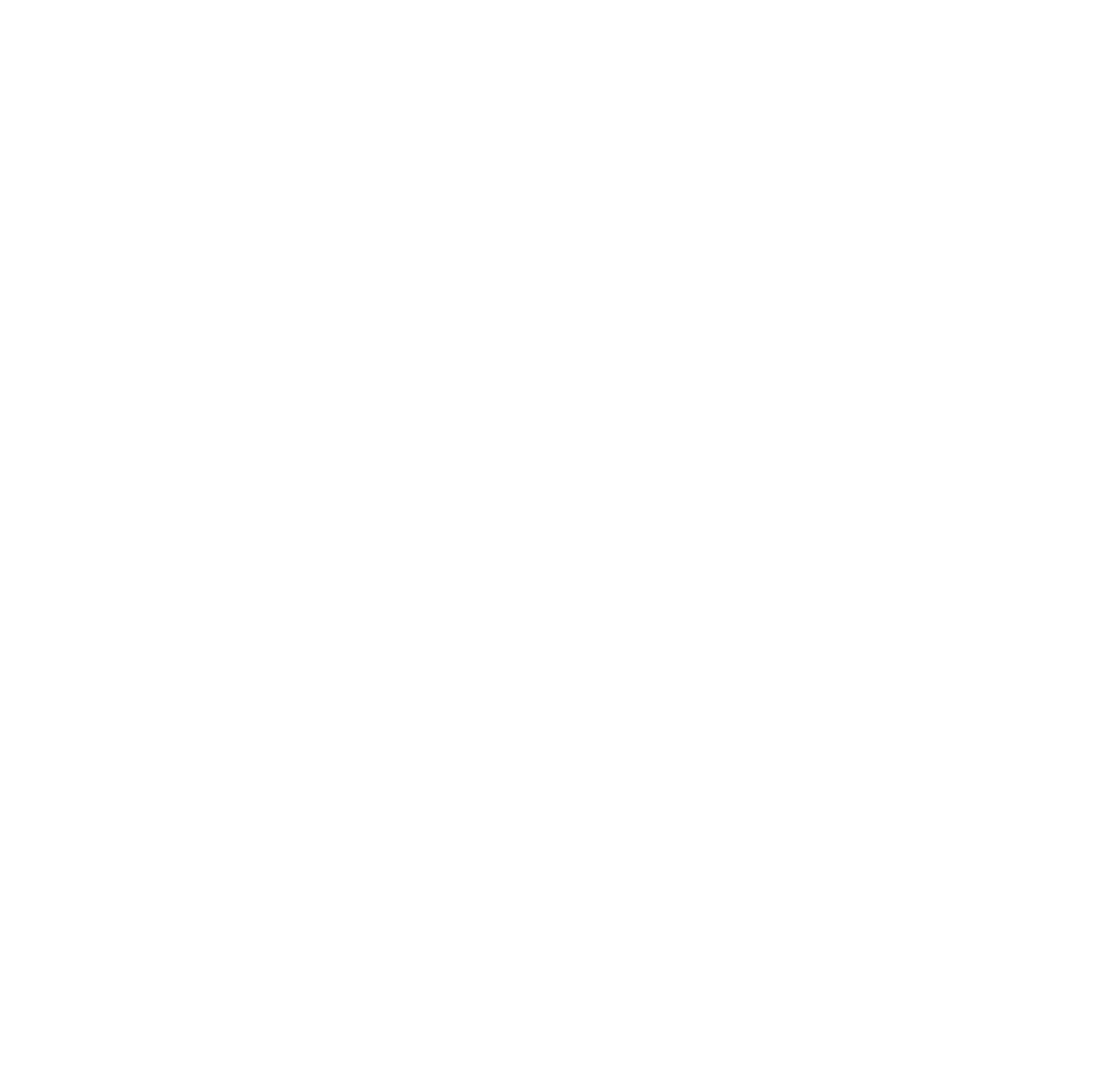

